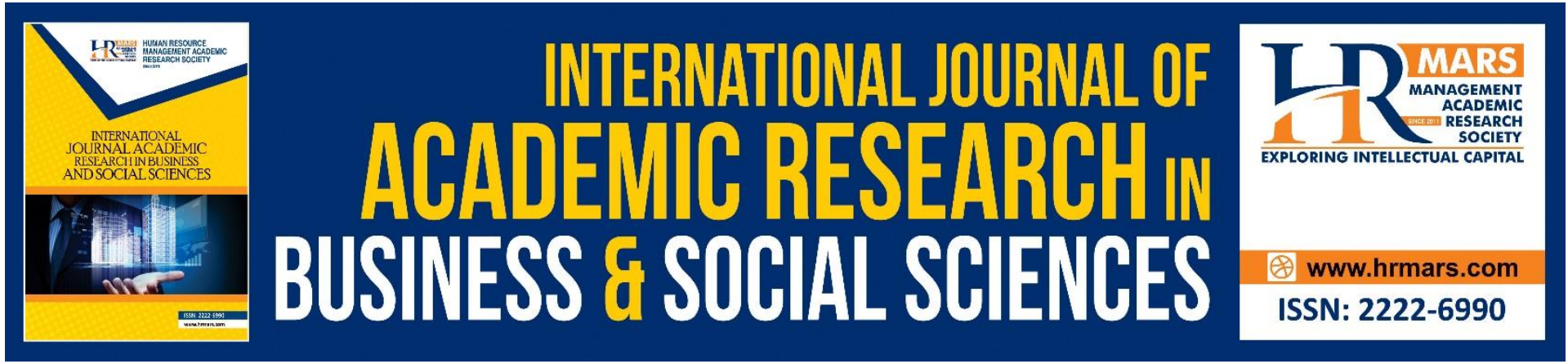

\title{
Issues, Challenges and Solutions of Aqidah Management in Malaysia
}

Sophian Rambli, Engku Ahmad Zaki Engku Alwi, Noor Emma Shamsuddin

To Link this Article: http://dx.doi.org/10.6007/IJARBSS/v11-i8/10799

DOI:10.6007/IJARBSS/v11-i8/10799

Received: 17 June 2021, Revised: 20 July 2021, Accepted: 04 August 2021

Published Online: 19 August 2021

In-Text Citation: (Rambli et al., 2021)

To Cite this Article: Rambli, S., Alwi, E. A. Z. E., \& Shamsuddin, N. E. (2021). Issues, Challenges and Solutions of Aqidah Management in Malaysia. International Journal of Academic Research in Business and Social Sciences, 11(8), 1076-1085.

Copyright: (c) 2021 The Author(s)

Published by Human Resource Management Academic Research Society (www.hrmars.com)

This article is published under the Creative Commons Attribution (CC BY 4.0) license. Anyone may reproduce, distribute, translate and create derivative works of this article (for both commercial and non-commercial purposes), subject to full attribution to the original publication and authors. The full terms of this license may be seen at: http://creativecommons.org/licences/by/4.0/legalcode

Vol. 11, No. 8, 2021, Pg. 1076 - 1085

Full Terms \& Conditions of access and use can be found at http://hrmars.com/index.php/pages/detail/publication-ethics 


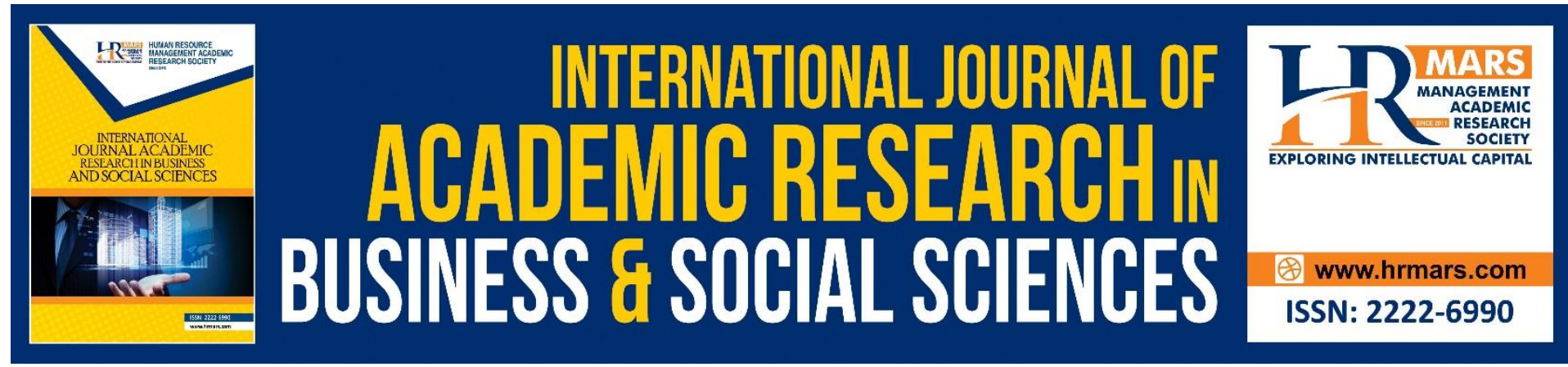

\title{
Issues, Challenges and Solutions of Aqidah Management in Malaysia
}

\section{${ }^{1}$ Sophian Rambli, ${ }^{2}$ Engku Ahmad Zaki Engku Alwi, ${ }^{3}$ Noor Emma Shamsuddin}

${ }^{1}$ Candidate Doctor of Philosophy, Graduate School, UniSZA, Faculty of Contemporary Islamic Studies, Universiti Sultan Zainal Abidin (UniSZA) Kampung Gong Badak Kuala Terengganu, Terengganu, ${ }^{2}$ Professor and lecturer, Faculty of Contemporary Islamic Studies, Universiti

Sultan Zainal Abidin (UniSZA), Kampung Gong Badak Kuala Terengganu, Terengganu,

${ }^{3}$ Lecturer, Faculty of Business Management, Universiti Teknologi MARA (UiTM) Sarawak, Mukah Campus

Email: sopet77@gmail.com,drzaki@gmail.com,emma.shamsuddin@gmail.com

\begin{abstract}
Aqidah is the main pillar in the hands of the Muslims and needs to be systematically and integrated handled. If this is not being done properly, it will lead to things that lead to disunity and deviation of Muslims. Islamic Development Department of Malaysia (JAKIM) is an Islamic institution entrusted with the responsibility for managing Islamic affairs, including aqidah management. Throughout the establishment, JAKIM faces various issues and challenges that must be addressed to professions and strategize in strengthening the holdings of Muslims in Malaysia. This is just not applicable for federal in Malaysia level only, but the states level as well. This paper discusses some of the issues and challenges faced by JAKIM as well as enhancing both the approach and synergistic approaches to the conduct of the aqidah in Malaysia. The method of this paper study uses interviews, observations and analysis of documents. The result of this study found various issues and challenges faced by JAKIM in dealing with the management of aqidah in Malaysia. In strengthening the aqidah of Muslims in Malaysia, JAKIM always uses methods, approaches and strategies in dealing with issues and challenges in managing the aqidah to stabilize the teachings of Islam and the holdings of Muslims in Malaysia.
\end{abstract}

Keywords: Issues, Challenges and Islamic Development Department of Malaysia (JAKIM).

\section{Introduction}

In recent times, internal issues in Malaysia and external links with Muslims have come to question credibility, authority and relevance, including Islamic agencies in Malaysia on the grounds of dissatisfaction with the various issues of small and large matters. This is the challenge of a Muslim majority country in addressing the issue of a terrible perception that will undermine the stability of the nation, including those of Islam who have long lived in harmony in the plurality of Malaysia. The writer is called upon to study more detail about the reasonableness of defending and strengthening Islamic agencies and institutions as a 
platform for the governance of Islamic affairs in Malaysia as in JAKIM empowered for the purity of Islam.

Furthermore, in order to ensure the continuity of the aqidah of Muslims, JAKIM in collaboration with the State Islamic Affairs Department (JAIN) and non-governmental organizations have organized various scientific and awareness programs such as symposium, seminars, forums, workshop and so on nationwide. This will enhance the understanding and appreciation of Muslims in various dimensions and containers to disseminate information on the strengthening of faith and community development at all levels and others. Furthermore, studies and actions on those who seek to spread the teachings or beliefs that contravene the Islamic creed should be monitored and reinforced with spaces to avoid threatening the position of Islam and the holdings of Muslims.

Strengthen the aqidah of the Sunnah of Wal-Jamaah in the scope of wasatiyyah and harmony. Malaysia is a country that makes flow and guidance the aspect of the aqidah of the Sunnah Wal-Jamaah members as the official holding in the Muslim community (JAKIM Strategic Plan 2015-2019). Referring to the Special Muzakarah of the Council of Fatwa of the National Council for Islamic Religious Affairs Malaysia held on May 5, 1996,

...Has stipulated that the ummah of Islam in Malaysia should be based only on the teachings of Islam based on the holdings of the Sunnah Wal-Jamaah in terms of shariah and morality.

\section{Literature Review}

Research on the role of JAKIM in the management of the Aid in Malaysia has yet to be highlighted. Although many studies have been highlighted in relation to JAKIM's role, contribution and others but from different aspects or areas and scope of different studies. The researcher will examine the research or research that has not been done by the previous researcher. Indeed the writings about JAKIM and also touch different aspects and perspectives. Among them are:

Badrulhisham (2015), Sunnah Wal Jamaah Member and Application in Malaysia, Issues and Challenges mentioning Sunnah Wal Jamaah members as a whole and in principle in its practice in Malaysia. But since then, various issues and challenges in celebrating the diversity of sectarian practices are practiced in Malaysia. Generally, this study illustrates the issues and challenges of Wasatiyyah and ASWJ concept approaches and strategies in dealing with khilafiyyah including aspects of the aqidah. Nevertheless, there is a need for further research and related research to the authors.

Mas'od (2013), Discussion of Islamic Issues and Thoughts in Malaysia explains and discusses the issue of aqidah in Malaysia such as its history and its development. Issues pertaining to the threat of aqidah and current thinking in Malaysia based on academic methodology, maintain scientific values and take reference from the authoritative authority to determine the position or official position of the relevant authorities on an issue. In his research includes various approaches ie whether it is a horizontal explanation or an argument against the deviant beliefs and thoughts of the Islamic aqidah and shariah.

Ibrahim (2013), Pengurusan Akidah Dalam Kehidupan Muslim which explains the doctrine of the aqidah is the thought of every individual. Hence, it needs to be taken care of and wellmanaged and well-established. On the other hand, failure to manage and arrange this will lead to confusion, deviation, division, collision and destruction in various aspects. And also that would have a negative impact on the Muslim world. 
The current reality of a relatively oppressed Muslim community in many parts of the world requires an easy and clear approach and clarification of the faith, which is to enable the unity and strengthening of Muslims, Awang (2014) Peranan dan Sumbangan JAKIM dalam Dialog Antara Agama, is a study of methodology in impacting the harmony and well-being of the Muslim community, including religious affiliation. The study focuses on dialogue as one of the effective approaches and tolerance to be done either individually or in groups. This research focuses only on dialogue approaches and practices conducted by the JAKIM and other Islamic agencies in establishing unity space among the various beliefs and beliefs in Malaysia.

Preston (2012), The State Islam Nexus, Islam and the State in Indonesia and Malaysia 19822008 , generally explains that in general discussions of the governance system practiced in Malaysia, researchers have shown comparisons between Malaysia and Indonesia have a majority of Muslims and practice life based on Islamic teachings. However, there is little discussion on the role of Islamic agencies, whether ideological based ideologies and Islamic struggles, Islamic institutions that govern and administer Islamic affairs.

Ibrahim (2006), Akidah dan Pembangunan Tamadun, in this book explains the aqidah in strengthening the development of Islamic civilization. This book helps in clarifying the aspect of the aqidahalso strengthens the holdings of Muslims albeit undergoing changes in civilization whether physical or material. This research discussion explains that Islam is a complete and comprehensive religion. And His teachings cover various aspects of life whether related to the world or the hereafter.

Daud (2005), Kesatuan IImu dan Amal Dalam Konteks Pentadbiran Beradab, Satu Kajian di JAKIM, focuses on the tradition of knowledge and educational development that JAKIM has done to uphold the Islamic sciences in Malaysia.

Noor (2005), Jabatan Kemajuan Islam Malaysia (JAKIM), Peranannya Dalam Pendidikan Sosial di Malaysia, in this study, it only explains JAKIM and its role in social education in general. Nevertheless there are other aspects of helping to study further in a comprehensive and indepth, especially the aspects of Islamic faith and thought.

Awang (2003), Usaha-usaha Pemurniah Akidah Islam: Analisi Khusus Terhadap Usaha-usaha Jabatan Kemajuan Islam Malaysia (JAKIM) dan Pusat Pemurniah Akidah Jabatan Agama Islam Selangor (JAIS) di Hulu Yam Bharu, Selangor. This study generally explains that approaches and methods conducted by two Islamic agencies namely JAKIM and JAIS in some places in Selangor. And this study also helps in looking at the efforts made by both Islamic agencies in purifying the Islamic aqidah. For researchers, the aspects of purification efforts in general can be done further studies in order to give a clearer and deeper picture of the next study.

In all this research, many of these researches provide advantages to research that will be done by researchers as information and data are discussed and debated are very relevant. This will be helpful in thorough and comprehensive research on studies not previously undertaken by previous researchers, particularly the role of Islamic agencies in the management of Islamic issues in Malaysia as the focus of research studies. In the book The Issue of Akidah dan Pemikiran Islam di Malaysia, it is a horizontal or more argument against the creed and deviant thinking of the Islamic aqidah and syariah.

Furthermore, after displaying the studies before there is still much space and things that have not been studied by other researchers. This will enable the researchers to focus on, study in depth and detail on this institution, JAKIM as a domain of study so that it can be used as a research that yields benefits not only to institutions ie JAKIM but also see the uniqueness, the role of reinforcing aqidah and Islamic thought in Malaysia. 
Previous studies can provide information on the strength of the study to assist researchers in the research to be undertaken in this research. Whereas the shortage will be given room for improvement and thoroughly examined for this scientific study to be fully understood by the whole discussion. Almost all previous researches have advantages and strengths and weaknesses in preliminary surveys and will continue. There is still space and other aspects that have not been studied and will be peeled and investigated by researchers. With deep discussions and discussions in this research, they are working on this investigation to improve the shortcomings and to be able to address those things that have not been discussed or reviewed by other researchers and to discover new things in this research.

The authors find that past studies do not focus JAKIM in depth and are only general in discussing roles and contributions. Researchers here will study, discuss and clarify in detail on JAKIM's 1968 history and development. In addition, researchers will study, explore and analyze the aspects of JAKIM's role in the management of the issues of aqidah in Malaysia. And then the researcher also discusses findings that have never been used by other researchers.

Having outlined some earlier studies, it is clear that there has been no study on the role of JAKIM in the management of the issues of aqidah in Malaysia from 1984 to 2016. Despite that earlier studies helped in the research that researchers would later research the fields for future research can contribute to knowledge, government, society, Muslims and Islamic institutions in Malaysia. Hopefully, with the findings and lactation of this study, it will be able to produce the works and treasures of Islamic history especially about Islamic institutions in Malaysia in particular explaining and understanding aspects of JAKIM's role in managing Islamic issues in Malaysia.

\section{Methodology}

As a guide in conducting this study, some of the methods identified can assist throughout this research process, namely, first library research Noah (2002) and Field Studies. While for Source and Customs Data Collection, writer uses semi structural Interview method, observation by Sang (2014) and document analysis. Research methodology is a systematic method for solving research problems. And it can be understood as a science to study how the study was conducted scientifically Kohtari (2004). In addition, the research methodology is also a method to be used either to collect data or to analyze data. The elaboration of this matter is important to look at the principles that are designed to achieve the proposed objectives. In a general this study is a more field study that uses qualitative research design concepts. Through qualitative studies, references to printed documentation and expert interviews have been used.

\section{Documentation}

This method is used to collect information and data from writing and written documentation that can provide evidence and is used as a valid proof of reality. It covers resources in the form of books, journals, pamphlets, dissertations and theses, seminar proceedings, papers, deeds, articles, reports, pamphlets and websites. The data obtained are used to form the basis of the theory as the basis for completing this study. It consists of primary and secondary sources.

Expert interviews

The interview method is used to obtain information directly about the subjects being studied. The interview method is very important because the issue is very sensitive and not 
all parties can properly describe it. Interviews are semi structured interviews where the questions submitted to the participant of the study are organized and determined but participant of the study is given the flexibility to respond and it can be expanded at the discretion of the interviewer by A.R (2016). Interviews with JAKIM Research Officers, JAKIM Criminal Jurisdiction Specialist Officers, Expert Committee Members of the Iranian Panel (the appointment of JAKIM comprised academics at IPT), SS Mufti States of Malaysia, State Islamic Religious Enforcement and Research Officers (MAIN), Religious Officers (State Islamic Religious Departments), Government Agencies (KDN, PDRM, Prisons Department), IPT Academics (UM, UKM, USIM, KUIN, UITM) and NGOs.

The above a mentioned participants of the study selected purposeful sampling from government officials, academicians and academics are aimed at obtaining views and opinions and scientific arguments to be used as sources and data and analyzed to answer the research discussions done. It can also be concluded that the researcher uses the method in analyzing the data about the research to be implemented ie:

Firstly, Inductive Method is a method that will explain and draw conclusions based on specific data that is about the reports and JAKIM records to make a general conclusion on the research to be conducted. Secondly, the Deductive Method will explain and make data analysis to produce conclusions based on interviews, research, articles and other data relating to Islamic developments in Malaysia and the general effectiveness and relevance of JAKIM to obtain specific conclusions in the end of this study. This is also to provide a report from the findings as well as what matters to the research results.

\section{Discussion}

Issues and problems that have always arisen in society require special attention by JAKIM. In this regard, JAKIM is incapable of and cannot move alone, but each issue and problem is taken seriously by Central and State Government agencies at all levels. This is because of the strength and unity in preventing and controlling the worse and more severe conditions if not concealed from the beginning and restricting from spreading and becoming the source of evolution and ultimately bringing disunity to Muslims in Malaysia. Among the key issues that are trained are related to deviant behavior, deviant teachings, hedonism culture (extreme amusement), moral impairment, social phenomena, security aspects, extremism issues, religious extremism, liberalism, pluralism, humanism, LGBT, etc.

Regarding the various issues and challenges faced by Muslims including in Malaysia, it is unsurpassed by threats and concerns to deal with mediocre approaches, modest and full of wisdom. This is because the main unions can become fortresses and shields to deal with and remain committed to the teachings of Islam. Thus, researchers found that JAKIM was the leading leader to resolve, to provide space and opportunity to co-exist with the rulers and the people in dealing with important and important issues of Islamic creeds and thoughts. Framework and Conceptual Issues and Challenges

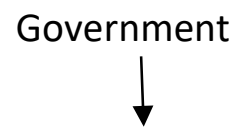

Institutional Managenment And Admiinstration In Islamic Affairs Fatwa (Evidence, Syariah and Legal Hakam)

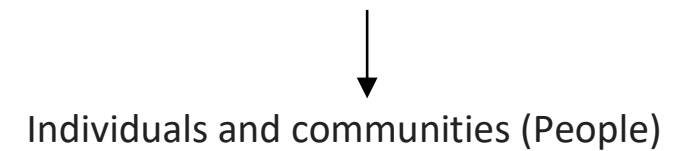


It is recognized that the fatwa institution can be likened to a cake baked from above and from below. The explanation is that, above, the fatwa institution is faced with the politics of government (government) and below is faced with the community (Muslims) who sometimes disagree with the decisions and provisions set by the government or the government as federal and state level. As such, a fatwa may be considered positive by the government or the government if it is judged to defend its interests and is negatively evaluated by the people (Muslims) because of the thought, perception and allegation that the fatwa issued on the abduction and enforcement and orders from the government.

Likewise, a fatwa can be judged negatively by the government if it is detrimental to its decision. There are other assessments such as Committee members (even Muslims) to establish cooperation or agreement. As a result, the possibility of arising from constraints will not be easy to obtain facilities in implementing programs or activities.

In its conclusions, globalization is unlikely to be prevented and the tone is continuously evolving even resulting in challenges to Islamic affairs institutions including fatwa decisions, therefore to be considered with the complex world, diversity. The vision and mission to be realized is to achieve and to invite good and to prevent evil. And also trying to apply Islam as ummatan wasathan, rahmah and li al-'alamin.

Allah said:

O mankind, indeed We have created you from male and female and made you peoples and tribes that you may know one another. Indeed, the most noble of you in the sight of Allah is the most righteous of you. Indeed, Allah is Knowing and Acquainted.

(Quran al-Hujurat 49:13)

The importance of the fascist unity, the unity of the goal (Maqasid al-Syariah), the unity of action, the unity in the face of the challenge is among these studies conducted in view of the extent to which the role of JAKIM in strengthening the aqidah, unity barrier factors in the stabilization and empowerment of Muslims and improving approaches in dealing with issues and challenges in managing Islamic issues in Malaysia. The world of infinite and fast information challenges must be faced with speed and vision and not waiving the balance and harmony and prosperity in Malaysia will be sustained and stabilized.

There is no doubt that despite the numerous and varied efforts that have been made, the dissemination and development of the teachings, misunderstandings and deviations and misconceptions in society are still widespread and dare to appear blatantly with various reasons such as fundamental rights and freedoms - certain interests regardless of sensitivity until speculation, skepticism and polemic appear in multiracial, religious and cultural societies.

In terms of respect and mutual respect between religious people and intense tolerance are reinforced trying to be duplicated as a result of fracture and chaos which is difficult to control and improve conditions like in other parts of the world. And also deviant teachings are still occurring and appear in several locations throughout the country using different methods, concealed behind certain establishments and difficult modus operandi to be identified due to the shifting location in the movement to spread their understanding, activities and thoughts to new members and enhancement of existing members. In the world of globalization, they are also traced to the sophistication of information technology and the new media as a medium to influence civil society. Subsequently this group has moved 
through a subtle and cunning approach and lies behind the platforms, platforms and principles of intellectual and human rights.

Based on the research conducted by the JAKIM and others for 2009-2014 period, a total of 95 deviant teachings have been identified to be active in the country. As a result of monitoring, supervision and action and enforcement, movement and development of the deviant teachings group can be contained even though not entirely. At least JAKIM tries to keep the symptoms of deviation from continuing to become cancerous and to bring about the confusion of the Muslim community in Malaysia.

Whereas the enforcement and implementation aspects are pro and contra, in accordance with the constitution and the law, the JAKIM is given the subject and jurisdiction as the coordinator and administrator in the affairs of Islam at the federal level. However, in the face of state-level restrictions, it is also necessary to consider the proposals and bureaucracies to prioritize the benefits of the ummah and the Islamic religion in Malaysia. (Ibrahim, 2018).

MECHANISM OF MANAGEMENT OF AKIDAH IN MALAYSIA: PROPOSAL

1. Management of the aqidah is one of the alternatives to the impact and benefits of affairs especially in dealing with threats to the aqidah in Malaysia.

2. The Wasatiyyah Strategy and Approach poses as a platform and parallel to current developments in order to be relevant and significant in dealing with issues and challenges, especially the aspect of the aqidah which is the core and fundamental strength of the Muslim aqidah and beliefs that need to be maintained and strengthened in Muslim life.

3. Adapted to the Index of the Aqidah that can control and monitor to be protected from deviation and manipulation.

4. The advantages and strengths of the position of Islam as the official foundation of the Muslims at the federation level and support tolerance and mutual respect in the difference in holdings, religions and beliefs.

5. Issues and challenges in particular aspects of the aqidah are dealt together with the strong link between the federal government and the states in Malaysia although at the same time have some constraints on the legal basis of states in Malaysia.

6. Strengthening the expertise of the Division of Jurisprudence Panel not only from the JAKIM but will be proposed to the states in Malaysia namely MAIN, JAIN and the Mufti Department of states in Malaysia to be established so that the agreement in coordination and control can be realized even though there are constraints both inside and outside.

7. The concept of Wasatiyyah and Sunnah Wal Jamaah in responding to the difference whether there will be issues and challenges that cause disunity and bad mood for Muslims. Hence this requires coordination and supervision with a professional approach and focusing on key benefits rather than creating disagreements with the unification and agreement between all parties including government, private and nonpublic organizations. Explanation and continuous understanding will reduce the thinking of the community more effectively and systematically. It will also explain to the public about manners and morals and methods of diverse principles, opinions and principles to keep the Muslim brotherhood alive.

\section{Conclusion}

The study suggests that further studies are conducted on agencies, especially those acting directly in managing, coordinating and handling programs, activities, strengthening 
workshops, monitoring, controlling, improving jurisdictions, more systematic restructuring and integrated in empowering the mechanisms for the management of the aqidah in Malaysia to strengthen planning and coordination in the management of the aqidah. The proposed akidah management module is likely to be useful in enhancing the specific management aspects of addressing the issues of aqidah, comprehensive religious beliefs and khilafiyyah issues, especially the aspects of the aqidah and contemplation.

These efforts to provide JAKIM's outstanding achievement to continue serving the community. Although JAKIM is sometimes bombarded with various issues, challenges, problems to carry out its aqidah management activities, JAKIM has prospects and will continue to address it from time to time.

\section{References}

Usop, A. (2017) (Mantan Setiausaha Kerja Gabungan Sunnah Malaysia, NGO) in discussion with researches, Disember $19^{\text {th }}$.

Abdullah. (2010). Teras Utama Sistem Pengurusan Islam, pp. 215. Kuala Lumpur: Alam Raya Enterprise.

Abdul Kadir, M. N. (2015). Aku Betul Engkau Sesat: Menekuni Jalan Damai Dalam Perbezaan, pp 44-51. Kuala Lumpur: Telaga Biru Sdn Bhd.

Ahmad, H. (Pengarah Bahagian Keluarga Sosial dan Komuniti di Jabatan Kemajuan Islam Malaysia (JAKIM)) in discussion with researcher, Februari 19, 2016.

Muhammad, Al-B. (1992).Pembangunan Pentadbiran Menurut Perspektif Islam. Translated by Abdullah Mohd. Noor, Kuala Lumpur: Dewan Bahasa Dan Pustaka.

Awang, M. (2003). Usaha-usaha Pemurnian Akidah Islam: Analisi khusus terhadap usahausaha Jabatan Kemajuan Islam Malaysia (JAKIM) dan Pusat Pemulihan Akidah Jabatan Agama Islam Selangor (JAIS) di Hulu Yam Bharu, Selangor, (tesis sarjana, Jabatan Akidah dan Pemikiran Islam, Bahagian Pengajian Usuluddin, Akademi Pengajian Islam, Universiti Malaya.

Che Omar, A. (2013). Pengenal Pengurusan Islam. Kuala Lumpur: Dewan Bahasa dan Pustaka.

Alwi, E. A. Z. (2007). Membangun Modal Insan Melalui Pemantapan Akidah, pp 13. Kuala Lumpur: Jabatan Kemajuan Islam Malaysia (JAKIM).

Hamat, M. (2002). Peranan Akidah Dalam Perancangan Pembangunan Ummah: Satu Analisis Dalam Konteks Masyarakat Kini.Jurnal Usuluddin, 16 (2002.02), pp13-14. Kuala Lumpur: Universiti Malaya.

JAKIM 4 DEKAD: Memacu Transformasi Pengurusan Hal Ehwal Islam. (2012) Putrajaya, Malaysia: Jabatan Kemajuan Islam Malaysia (JAKIM).

Laporan Tahunan Jabatan Kemajuan Islam Malaysia. (2014). Kuala Lumpur: Jabatan Kemajuan Islam Malaysia (JAKIM).

Mas'od, M. A. (2015). Diskusi Isu Aqidah dan Pemikiran Islam di Malaysia. Wilayah Persekutuan: Jabatan Kemajuan Islam Malaysia (JAKIM).

Mas'od. (2016) M. A. (Pegawai Hal Ehwal Islam Bahagian Akidah di Jabatan Kemajuan Islam Malaysia (JAKIM)) in discussion with researcher, January.

Noor, M. N. (2005). Jabatan Kemajuan Islam Malaysia (JAKIM): peranannya dalam pendidikan sosial di Malaysia. Tesis sarjana, Jabatan Sejarah dan Tamadun Islam, Akademi Pengajian Islam: Universiti Malaya.

Yassin, M. M. (2005). Penyelarasan Pentadbiran Hal Ehwal Islam Malaysia: Kajian di Jabatan Kemajuan Islam Malaysia (JAKIM), (tesis kedoktoran, Jabatan Pengurusan, Bahagian Pengajian Syariah, Akademi Pengajian Islam, Universiti Malaya. 
Wan Daud, W. R. (2005). Kesatuan ilmu dan amal dalam konteks pentadbiran beradab: Satu kajian di JAKIM, (tesis sarjana, Pengajian Peradaban, Fakulti Sastera \& Sains Sosial, Universiti Malaya. 